\title{
Identifikasi Bakteri Patogen Pada Olahan Pangan Saat Arus Mudik Lebaran Di Terminal Tirtonadi Surakarta
}

\author{
Afifah Nurul Falih ${ }^{1}$, Nosa Septiana Anindita ${ }^{2}$, Emmanuel Kristanti $^{3}$ \\ ${ }^{1,2}$ Universitas 'Aisyiyah Yogyakarta. Jalan Siliwangi No. 63 Mlangi, Nogotirto, \\ Gamping, Sleman, Yogyakarta, Indonesia \\ Email: ${ }^{1}$ afifahn192@gmail.com, ${ }^{2}$ nosa.nindita@unisayogya.ac.id \\ ${ }^{3}$ Balai Teknik Kesehatan Lingkungan dan Pengendalian Penyakit Yogyakarta, Indonesia \\ Email: ${ }^{3}$ noelkris27@gmail.com
}

Tanggal Submisi:5 Juni 2020; Tanggal Penerimaan: 27 Februari 2021

\begin{abstract}
ABSTRAK
Keamanan pangan pada olahan pangan yang diperjual belikan menjadi perhatian bagi masyarakat terutama akibat yang ditimbulkan. Oleh karena itu, perlu dilakukan tindakan pengawasan melalui identifikasi terkait keberadaan bakteri patogen pada olahan pangan. Tujuan dari penelitian ini adalah mengidentifikasi keberadaan bakteri patogen dalam olahan pangan selama mudik lebaran di Terminal Tirtonadi Surakarta. Metode identifikasi yang digunakan meliputi pengambilan dan pengkayaan sampel, uji konfirmasi, uji penegasan dan analisis data. Hasil yang didapatkan dari penelitian ini yaitu dari 11 sampel olahan pangan, semua sampel hasil yang diperoleh negatif (-) terhadap bakteri Salmonella sp, Vibrio cholera (V.cholera), Staphylococcus aureus (S. aureus), Bacillus cereus (B. Cereus) akan tetapi 6 sampel teridentifikasi positif (+) cemaran Eschericia coli (E.coli). Sehingga, dapat disimpulkan bahwa dari beberapa jenis bakteri patogen sebagai indikator cemaran olahan bahan pangan, terdapat satu cemaran bakteri patogen yang positif ditemukan dalam 6 sampel olahan pangan yaitu E.coli.
\end{abstract}

Kata kunci : Bakteri patogen, escherichia coli, keamanan pangan,

\begin{abstract}
Processed food security in food traded being attention to the community mainly due to inflicted. Therefore, needs to be done the act of surveillance by identification related the existence of pathogenic bacteria in processed food. The purpose of the research is identification pathogenic bacteria in prosecced food during mudik lebaran in Tirtonadi Bus Station Surakarta. Identification method instruments consist of sample enrichment, confirmation test, affirmation test and data analysis. The result of this research from 11 sample processed food, this all sample result is negative on the bacterium Salmonella sp, Vibrio cholera (V. cholera), Staphylococcus aureus (S. aureus), Bacillus cereus (B. cereus) but 6 sample result confirmed is positive on bacteria Eschericia coli (E. coli). So, that it can be concluded that some kind of pathogenic bacteria as an indicator of prosecced food, there is one positive pathogenic bacteria found in 6 sample processed food the Eschericia coli bacteria.
\end{abstract}

Keywords: Pathogenic bacteria, Eschericia coli, food security 
ISSN 1979-7621 (Print). ISSN 2620-7761 (Online)

DOI : $10.23917 / j k . v 14 i 1.11056$

\section{PENDAHULUAN}

Keamanan pangan menjadi isu yang sangat diperhatikan karena frekuensi terjadinya penyakit yang disebabkan dari bahan dan olahan pangan sangat berpotensi tinggi terkontaminasi bakteri patogen. Hal ini merupakan masalah utama terutama di negara-negara berkembang. Menurut Kurniadi et al. (2013), penyakit yang berasal dari olahan pangan berawal dari higienitas dan kondisi sanitasi di lingkungan sekitar pengolahan bahan pangan. Pernyataan tersebut juga di dukung oleh Arlita pada tahun 2003 yang menyatakan bahwa penyakit bawaan makanan (foodborne disease) adalah penyakit yang ditimbulkan oleh makanan yang disebabkan adanya kontaminasi yang terdapat di dalam bahan pangan yang kita konsumsi sehari-hari.

Bahan pangan yang sering mengalami pencemaran ataupun mudah terkontaminasi adalah makanan siap saji. Makanan siap saji khususnya yang dijual oleh para pedagang kaki lima sangat beresiko terjadinya kontaminasi. Hal tersebut disebabkan karena kualitas air yang tidak memenuhi syarat, pembuangan sampah sembarangan, higienitas yang kurang baik dan tidak terdapat sanitasi di lingkungan sekitar. Berdasarkan penelitian Ruriani dan Nurhayati pada tahun 2010 sumber yang paling sering menyebabkan keracunan adalah penggunaan nasi yang sudah dingin yang dilakukan pengolahan ulang. Hal tersebut sangat diwaspadai karena memungkinkan akan terjadinya kontaminasi oleh bakteri Bacillus cereus. Penelitian tersebut juga di dukung oleh Ekawati et al. (2017) yang menyatakan bahwa kasus keracunan juga dapat terjadi akibat adanya bakteri yang mengkontaminasi dan berkembang biak pada saat proses penyimpanan. Proses penyimpanan yang tidak sesuai dapat menghasilkan senyawa toksin yang dikeluarkan oleh bakteri.

Bakteri yang sering mencemari bahan pangan tidak semuanya menyebabkan penyakit yang sama. Masing-masing bakteri mampu mengeluarkan senyawa enterotoksin yang berbeda, sehingga penyakit yang di munculkan juga berbeda. Habitat masing-masing bakteri tersebut juga berbeda, tidak semua bakteri dapat tumbuh pada bahan pangan orang dewasa, namun dapat tumbuh pada bahan pangan bayi. Penyakit akibat keracunan makanan di Indonesia dapat dikatakan terus mengalami peningkatan di setiap tahunnya. Kejadian keracunan makanan rata-rata ditemukan pada makanan yang berasal dari jajanan yang diperjual belikan oleh pedagang kaki lima.

Oleh karena itu, perlu dilakukan suatu penelitian terkait pengawasan pada olahan pangan yang diperjual belikan oleh pedagang kaki lima terutama pada saat arus mudik lebaran yang dikonsumsi oleh masyarakat. Pengawasan dan penelitian bahan pangan ini bertujuan untuk menghindari terjadinya kejadian luar biasa (KLB) berupa keracunan makanan pada saat arus mudik lebaran. Besar harapan dari penelitian dan pengawasan bahan pangan tersebut dapat diambil sebuah kesimpulan yaitu terkait dengan rencana tindak lanjut dari pemerintah apabila terjadi KLB keracunan saat arus mudik lebaran. 


\section{METODE PENELITIAN}

\section{Waktu dan Tempat}

Penelitian ini merupakan studi

kasus KLB yang dilakukan secara eksperimental dengan skala laboratorium. Penelitian ini dilakukan pada tanggal 27 April hingga 8 Mei 2019 di Balai Besar Teknik Kesehatan Lingkungan dan Pengendalian Penyakit (BBTKLPP) Yogyakarta.

\section{Alat dan Bahan}

Alat. Alat yang digunakan pada penelitian ini diantaranya adalah botol duran steril, bunsen, sendok steril, plastik steril, ice pack, cool box, petridish, autoklaf, Biological Safety Cabinet (BSC), oven, refrigerator, bunsen, botol kecil, jarum ose, panel Negative Identification, panel Positive Identificaton, Inventory Lab dan vortex.

Bahan. Bahan yang digunakan pada penelitian ini diantaranya adalah aquades, sampel makanan siap saji, Brain Heart Infusion (Oxoid), Alkaline Peptone Water (Becton Dickinson), selenite (Becton Dickinson), Salmonella-Shigella

(Becton Dickinson), Chromocult (Merck), Xylose Lysine Deoxycholate (Oxoid), Ethyl Methylene Blue (Becton Dickinson), Mac Conkey (Becton Dickinson), Thiosulfate Citrate Bile Salt Sucrose (Becton Dickinson), Manitol Salt Agar (Becton Dickinson), Trypticase Soy Agar (Becton Dickinson).

\section{Pengambilan Sampel}

Sampel diambil dari beberapa warung makan yang menjual olahan pangan siap saji di Terminal Tirtonadi. Warung makan yang digunakan sebagai sampel diambil 2 hingga 3 jenis olahan pangan yang diperjual belikan. Sampel pangan yang akan dilakukan pengujian diambil secara aseptis yaitu menggunakan alat yang sudah steril. Sampel pangan tersebut selanjutnya dismpan dalam wadah khusus dan disimpan dalam cooler box.

\section{Pengkayaan sampel}

Pengkayaan sampel pangan pada penelitian ini menggunakan metode Swanburg et al., (2001). Media yang digunakan terdpat tiga jenis media cair yaitu media selenite, $\mathrm{BHI}$ dan APW. Pengkayaan sampel dilakukan dengan cara mengambil sebagian contoh uji kemudian dimasukkan ke dalam botol menggunakan sendok. Sampel yang sudah di campurkan ke dalam media, kemudian di inkubasi menggunakan inkubator pada suhu $35^{\circ} \mathrm{C}$ selama 24 jam.

\section{Uji konfirmasi}

Penguajian ini dilakukan berdasarkan metode Turrner et al.,(2000) yang sudah di modifikasi. Sampel yang sudah di perkaya dan di inkubasi selama 24 jam ditanam ke dalam media agar selektif. Media agar yang digunakan yaitu XLD, SS, Cr, EMB, MSA, TSA dan TCBS. Koloni yang sudah ditanam dalam media agar, selanjutnya di inkubasi menggunakan inkubator selama 24 jam pada suhu $35^{\circ} \mathrm{C}$ dan dilakukan pengamatan. Koloni yang telah dilakukan pengamatan tersebut kemudian dimasukkan ke dalam media selenite untuk meregenerasi pertumbuhan koloni. Media yang digunakan untuk pengkayaan koloni bakteri yaitu media selenite kemudian inkubasi selama 24 jam pada suhu $35^{\circ} \mathrm{C}$. 


\section{Uji Penegasan}

Uji penegasan dilakukan menggunakan metode yang sudah dimodifikasi pada penelitian Sari dan Apridamayanti (2014) yaitu dengan cara menggoresskan koloni di atas media agar MC dan TSA. Kemudian dilakukan inkubasi kurang dari 24 jam pada suhu $35^{\circ} \mathrm{C}$. Kemudian dilakukan seleksi berdasarkan morfologi yang sesuai dengan bakteri patogen untuk dilakukan pengujian senyawa biokimia menggunakan mesin Inventory Lab untuk menegaskan jenis bakteri.

Proses ini dilakukan dengan cara mengambil koloni yang terdapat pada media kemudian dimasukkan ke dalam cairan Negative Identification (NID) untuk bakteri gram negatif dan Positive Identification (PID) untuk bakteri gram positif. Kemudian cairan di vortex dan dilakukan pengukuran yaitu menggunakan Nephlometer dengan jumlah koloni pada rentang 0,5 $0,6 \mu$. Cairan tersebut selanjutnya dituang ke dalam panel sesuai dengan cairan yang digunakan. Panel yang sudah terisi cairan, kemudian di tutup dan dimasukkan ke dalam mesin Inventory Lab.

\section{Analisis data}

Data di analisis secara kualitatif berdasarkan dari hasil uji biokimia menggunakan alat Inventory Lab.

\section{HASIL DAN PEMBAHASAN}

\section{Pengkayaan Sampel}

Pengkayaan sampel makanan

dan minuman bertujuan untuk meregenerasi bakteri yang terdapat di dalam sampel. Pengkayaan sampel makanan ini menggunakan tiga macam media yaitu BHI, APW dan selenite.
Media BHI dan selenite digunakan untuk memperkaya sampel makanan, sedangkan media APW digunakan untuk memperkaya sampel minuman. Jenis bakteri yang diperkaya dari masing-masing media juga berbeda.

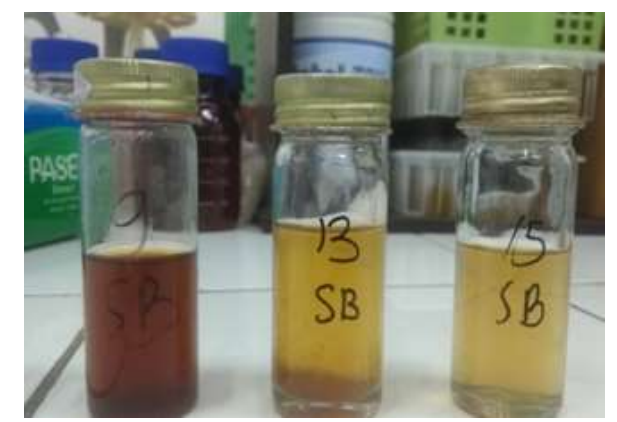

Gambar 1. Pengkayaan sampel minuman menggunakan media APW.

Pengkayaan menggunakan media APW seperti Gambar 1 ini bertujuan untuk meregenerasi bakteri Vibrio cholera. Proses pengkayaan menggunakan APW ini diperkuat dengan pendapat Sariadji, et al (2015) yang menyatakan bahwa menggunakan media APW bertujuan untuk meregenerasi bakteri Vibrio cholera $(V$. cholera). Bakteri $V$. cholera ini biasanya ditemukan pada sampel jenis minum, karena bakteri ini mudah tumbuh di air. Berdasarkan penelitian Sariadji et al., (2015) bahwa menggunakan medium APW untuk meregenerasi bakteri $V$. cholera memiliki waktu pertumbuhan yang sangat cepat dan merupakan waktu pertumbuhan yan optimal. Pada penelitiannya waktu yang dibutuhkan untuk menumbuhkan bakteri $V$. cholera yaitu selama 8-15 menit untuk satu fase pertumbuhan. Dalam waktu 8 jam sudah dapat menumbuhkan $1,5 \times 10^{12}$ bakteri $V$. cholera. 


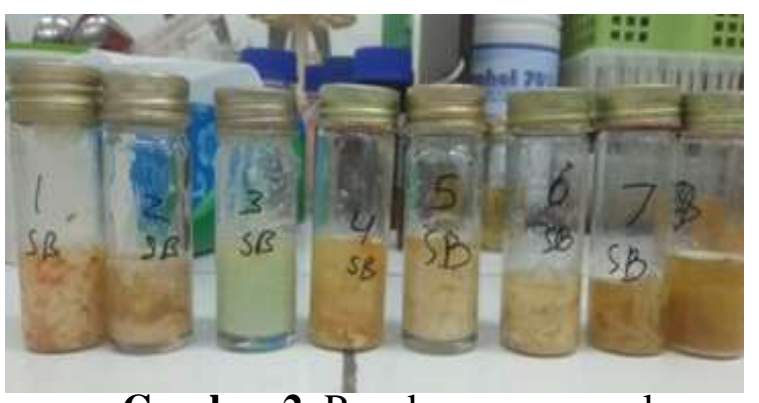

Gambar 2. Pengkayaan sampel menggunakan media $\mathrm{BHI}$

Pengkayaan menggunakan media BHI seperti Gambar 2 sering digunakan untuk memperkaya sampel makanan dan minuman. Media ini bertujuan untuk meregenerasi pertumbuhan bakteri Salmonella dan Shigella. Proses pengkayaan sampel makanan dan minuman menggunakan media BHI diperkuat dengan pendapat Yunus et al. (2017) yang menyatakan bahwa sampel makanan dengan menggunakan media BHI digunakan untuk meregenerasi bakteri Salmonella sp dan Shigella. Bakteri ini sangat mudah ditemukan pada makanan terutama pada jajanan sekolah dan makanan yang dijual oleh pedagang kaki lima. Pengkayaan menggunakan media BHI ini pada sampel makanan dapat ditandai dengan tingkat kekeruhan media. Media yang semakin keruh menandakan sampel tersebut positi terdapat bakteri patogen terutama bakteri Salmonella sp dan Shigella.

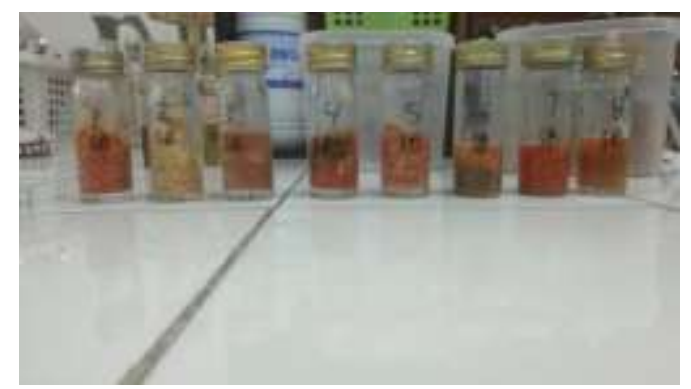

Gambar 3. Pengkayaan sampel menggunakan media selenite
Pengkayaan menggunakan selenite seperti Gambar 3. bertujuan untuk meregenerasi pertumbuhan

bakteri E. coli dan coliform pada sampel makanan dan minuman. Menurut Kartika et al (2014), pengkayaan sampel makanan dan minuman dengan menggunakan media selenite yaitu untuk meregenerasi keberadaan bakteri $E$. coli dan Coliform yang merupakan indikator keamanan pangan. Keberadaan bakteri pada sampel makanan dapat dilihat dari warna yang berbeda-beda. Masingmasing sampel memiliki warna yang berbeda sesuai dengan jenis bakteri yang terdapat pada sampel makanan.

\section{Uji Konfirmasi}

Penanaman koloni yang telah dilakukan sesuai dengan media selektif, sehingga koloni tersebut dapat tumbuh secara optimal. Selain itu, penanaman koloni pada media agar selektif ini juga disesuaikan dengan media pengaya yang digunakan sebelumnya. Hasil dari uji konfirmasi ini apabila positif maka pada permukaan agar akan tumbuh koloni dan apabila negatif maka tidak akan muncul koloni dan hanya bekas goresan saat strake seperti pada Gambar 5.
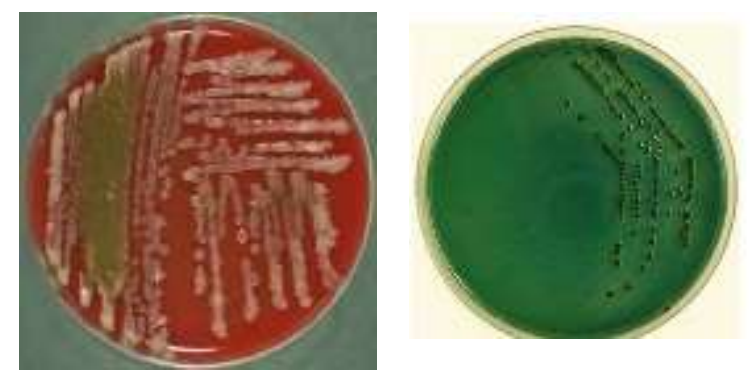

Gambar 5. Uji konfirmasi menggunakan media XLD dan TCBS

Wahdiniati et al. (2016) menyatakan bahwa penanaman koloni 
bakteri menggunakan media EMB digunakan untuk melihat keberadaan bakteri terutama yang termasuk ke dalam bakteri Gram positif seperti Salmonella sp dan E. coli. Berdasarkan penelitian Widiyanto pada tahun 2017 untuk melihat keberadaan bakteri $E$. coli pada sampel bahan pangan dapat menggunakan media $\mathrm{Cr}$. Koloni yang ditanamkan pada kedua media agar tersebut berdasarkan Kartika et al.(2014) sebelumnya dilakukan pengayaan mengunakan media selenite yang berfungsi untuk meregenerasi keberadaan bakteri E.coli dan bakteri Coliform.

Penanaman koloni bakteri juga dilakukan menggunakan media SS. Wahdiniati et al. (2016) pada penelitian yang telah dilakukan menyatakan bahwa media SS ini merupakan media selektif dan spesifik untuk pertumbuhan Salmonella sp. Berdasarkan penelitian Surjawidjaja et al pada tahun 2016 media SS ini juga memiliki kemampuan mendeteksi keberadaan bakteri Shigella, akan tetapi keberadaannya pada media ini lebih rendah dari bakteri Salmonella sp. Selaras dengan pernyataan sebelumnya Surjawidjaja et al.(2016) menyatakan bahwa terdapat media lain yang dapat digunakan untuk pengamatan bakteri Salmonella sp yaitu XLD. Media XLD ini keberadaan bakteri Shigella yang lebih tinggi daripada Salmonella sp. Berdasarkan Yunus et al.(2014) media SS dan XLD ini hanya berfungsi sebagai media konfirmasi setelah dilakukan pengkayaan koloni bakteri menggunakan media BHI.

Media selektif lain yang digunakan untuk menumbuhkan koloni adalah media TSA. Media TSA ini merupakan media universal untuk mengkonfirmasi keberadaan koloni bakteri Gram positif salah satunya adalah bakteri Staphylococcus aureus (S. aureus). Menurut Kartika et al. (2014), media TSA memiliki kandungan asam amino dan substansi nitrogen yang dapat digunakan untuk nutrisi pertumbuhan bakteri terutama bakteri patogen. Kartika et al. (2014) juga menyatakan bahwa untuk pengamatan bakteri $S$. aureus dapat menggunakan media agar TSA sebagai media pertumbuhan pada saat dilakukan uji konfirmasi. Selain itu, penggunaan media MSA dan TSA dilakukan setelah sampel diperkaya menggunakan media selenite

Keberadaan bakteri pada minuman juga dapat dikonfirmasi menggunakan media TCBS. Media TCBS ini merupakan media yang spesifik dengan pertumbuhan koloni $V$. cholera. Sariadji et al.(2015) pada penelitian yang dilakukannya menyatakan bahwa bakteri tersebut sangat sering ditemukan di minuman atau air yang sudah tercemar. Media TCBS ini juga merupakan media konfirmasi dari sampel yang sebelumnya di perkaya menggunakan APW yang sangat selektif terhadap pertumbuhan $V$. cholera. Sampel yang positif terdapat $V$. Cholera akan muncul koloni dengan warna mencolok, apabila sampel negatif hanya muncul bekas goresan pada saat strake.

\section{Uji Penegasan}

Uji penegasan dilakukan dengan cara koloni yang sudah diperbanyak menggunakan media selenit digoreskan di atas media agar. Media agar yang digunakan pada uji penegasan yaitu media MC dan TSA. Media yang digunakan hanya terdapat dua jenis, karena untuk melihat sifat 
bakteri tersebut yaitu gram negatif atau gram positif. Kedua media tersebut merupakan media universal yang digunakan untuk mengetahui sifat bakteri pathogen seperti Gambar 6 .

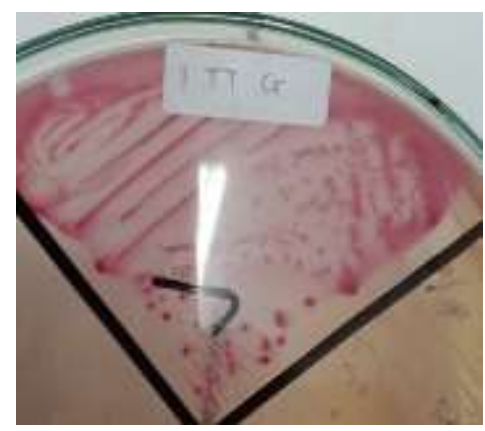

Gambar 6. Uji Penegasasan menggunakan media MC

Berdasarkan penelitian Habullah et al pada tahun 2015 bahwa uji penegasan yang menggunakan media MC bertujuan untuk menghambat pertumbuhan bakteri non patogen dan menumbuhkan bakteri patogen. Kemampuan media tersebut disebabkan karena adanya proses fermentasi laktosa menjadi asam dengan ditandai perubahan warna media. Selain itu, pada uji penegasan juga dapat dilakukan menggunakan media TSA. Penggunan media TSA tersebut berdasarkan pada penelitian Kartika et al.(2014) menyatakan bahwa penggunaan media TSA tersebut bertujuan untuk mengidentifikasai bakteri Gram negatif yang dapat memfermentasi glukosa atau laktosa.

Koloni bakteri yang diduga termasuk ke dalam bakteri patogen yang bersifat Gram negatif maupun positif, selanjutnya dilakukan pembacaan jenis koloni bakteri yang hidup berdasarkan senyawa biokimia yang terdapat pada koloni bakteri. Pembacaan koloni bakteri menggunakan mesin Inventory Lab.
Pembacaan koloni dilakukan dengan cara mengambil koloni yang terdapat pada media kemudian dimasukkan ke dalam cairan sesuai dengan sifat bakteri. Cairan yang digunakan terdapat dua jenis yaitu Negative Identification (NID) dan Positive Identification (PID). Cairan NID digunakan untuk bakteri yang bersifat gram negatif. Sedangkan PID digunakan untuk bakteri yang bersifat gram positif.
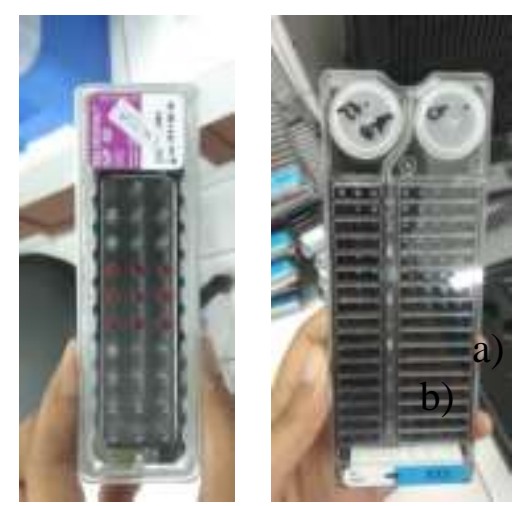

Gambar 7. Uji penegasan menggunakan Inventory Lab. a) Negative Identification (NID), b) Positive Identification (PID)

\section{Hasil Identifikasi}

Kegiatan terkait dengan identifikasi bakteri patogen saat arus mudik lebaran dilakukan secara berkala yaitu melalui pemantauan keamanan bahan pangan di setiap tahunnya menjelang kegiatan arus mudik lebaran berlangsung. Parameter yang digunakan yaitu terkait dengan E. coli, $V$. cholera, S. aureus, Salmonella $s p$ dan B. cereus.

Sampel yang akan dilakukan pengujian yaitu berupa makanan dan minuman yang diperjualbelikan kepada masyarakat. Jenis sampel yang diambil merupakan sampel yang memiliki frekuensi penjualan tertinggi di setiap warung makan yang berada di 
Terminal Tirtonadi Surakarta. Selain itu, sampel yang diambil juga diduga paling mudah terkontaminasi mikroorganisme patogen sehingga menyebabkan munculnya penyakit bawaan makanan (foodborne disease).

Berdasarkan hasil pengujian (Tabel 1) menunjukkan bahwa sampel makanan yang positif mengandung bakteri $E$. coli diantaranya adalah ayam goreng, pecel dan gado-gado. Berdasarkan penelitian yang telah dilakukan oleh Kurniasih et al.(2015) menyatakan bahwa ayam goreng dapat terkontaminasi bakteri E. coli.
Kontaminasi tersebut dapat terjadi disebabkan karena kondisi higienitas dan sanitasi yang kurang pada tempat pengolahan makanan dan penyaji makanan. Hal ini didukung oleh pendapat Rahmani dan Handayani (2016), bahwa bakteri E. coli dikaitkan dengan higienitas dan sanitasi karena bakteri tersebut merupakan salah satu indikator mikrobiologis makanan yang menurut keputusan Menteri Kesehatan keberadaan bakteri tersebut dalam makanan harus benar-benar negatif atau tidak ada sama sekali.

Tabel 1. Hasil cemaran bakteri patogen pada olahan pangan asal terminal Tirtonadi,

\begin{tabular}{|c|c|c|c|c|c|c|}
\hline \multirow{2}{*}{ No. uji } & \multirow{2}{*}{ Contoh uji } & \multicolumn{5}{|c|}{ Cemaran Mikroorganisme } \\
\hline & & E. coli & Salmonella $s p$ & V. cholera & S. aureus & B. cereus \\
\hline 08772 & Ayam Goreng & + & - & - & - & - \\
\hline 08773 & Pecel & - & - & - & - & - \\
\hline 08774 & Pecel & - & - & - & - & - \\
\hline 08775 & Jus & + & - & - & - & - \\
\hline 08776 & Gado-Gado & - & - & - & - & - \\
\hline 08777 & Pecel & + & - & - & - & - \\
\hline 08778 & Es Teh & + & - & - & - & - \\
\hline 08779 & Es Teh & + & - & - & - & - \\
\hline 08780 & $\begin{array}{l}\text { Oseng-Oseng } \\
\text { Buncis }\end{array}$ & - & - & - & - & - \\
\hline 08781 & Ayam Goreng & + & - & - & - & - \\
\hline 08782 & Es Teh & - & - & - & - & - \\
\hline
\end{tabular}

Sampel yang positif terdapat bakteri E. coli selain ayam goreng adalah pecel dan gado-gado. Kedua sampel tersebut terbukti terkontaminasi E. coli menurut Yuniatun et al. (2017), hal ini dapat disebabkan karena higienitas dan sanitasi tempat pegolahan makanan dan pengolah makanan yang belum mencuci tangan menggunakan sabun sebelum proses pengolahan. Selain itu, dapat juga cemaran tersebut disebabkan karena lokasi warung yang berada di jalur bus sehingga debu dan asap yang berasal dari bus mampu mengkontaminasi bahan pangan yang diperjual belikan.

Pada sampel minuman juga terdapat dua sampel yang positif mengandung bakteri $E$. coli yang berasal dari minuman es teh. Minuman es teh dapat tercemar bakteri tersebut diduga disebabkan karena air yang digunakan untuk pengolahan es teh. Rahmani dan Handayani (2016) pada penelitiannya menyatakan bahwa air yang mencemari es teh biasanya berasal dari air yag menjadi bahan baku es balok. Tercemarnya air yang digunakan dapat juga disebabkan 
karena feses dan kurangnya kesadaran pada para penyaji maupun penjaja es terkait higienitas suatu bahan makanan.

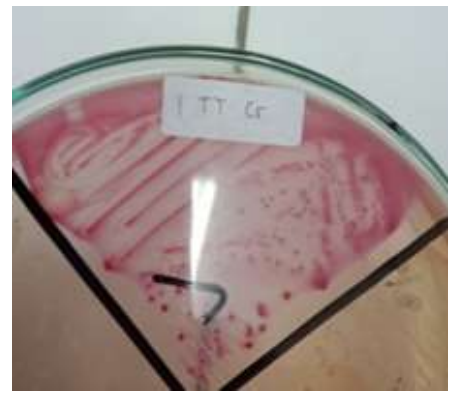

Gambar 10. Hasil morfologi bakteri E.coli pada media MC

Berdasarkan hasil identifikasi mikroorganisme patogen yang menyebabkan foodborne disease yaitu adanya cemaran $E$. coli pada makanan dan minuman yang diperjualbelikan di sekitar terminal Tirtonadi Surakarta. Sampel yang positif terdapat cemaran mikroorganisme E. coli sebanyak lima sampel dari sebelas sampel yang diambil. Bentuk bakteri E. coli yang tumbuh pada media EMB dapat dilihat pada Gambar 4. Hasil dari identifikasi bakteri tersebut berdasarkan dengan jenis senyawa biokimia yang terdapat pada bakteri tersebut.

Keberadaan E.coli pada bahan pangan merupakan indikasi dari sanitasi lingkungan sekitar pengolahan yang tidak baik. Hal tersebut selaras dengan pendapat Kurniadi et al.(2013) yang menyatakan bahwa bakteri $E$. coli penularannya dapat melalui tangan dan mulut serta melalui perpindahan secara pasif yaitu melalui makanan, air dan beberapa produk lainnya. Selain itu, menurut Rahayu (2003) dalam Kurniadi et al.(2013) persebaran bakteri E. coli sangat mudah dan cepat menjadi salah satu faktor tingginya kasus foodborne disease karena infeksi bakteri pada bahan pangan. Oleh karena itu, keberadaan bakteri E. coli pada bahan pangan dapat dikatakan memiliki korelasi tinggi dengan ditemukannya bibit penyakit pada bahan pangan tersebut.

Terjadinya resiko penularan mikroorganisme pada bahan pangan yaitu berawal pada saat proses pengolahan yang tidak bersih. Arlita $e t$ al.(2013) pada penelitiannya menyatakan bahwa pengolahan bahan pangan yang buruk menjadi awal tumbuhnya mikroorganisme pada bahan pangan. Selain itu, resiko tumbuhnya mikroorganisme juga dapat tumbuh pada saat proses penjualan bahan pangan yang tidak memperhatikan tingkat kebersihan dan keamanan pangannya. Selaras dengan pernyataan Aminah dan Nur pada penelitiannya tahun 2006 yang menyatakan bahwa resiko terjadinya kasus foodorne disease dapat diperkecil yaitu dengan cara memperhatikan pada saat proses pembuatan, distribusi hingga penyajian. Proses tersebut merupakan hal terpenting yang menjadi penentu munculnya risiko terkait dengan kesehatan manusia.

Kontaminasi bakteri patogen selain dapat memperkecil resikonya melalui proses produksi juga dapat diperkecil resikonya melalui prinsip higiene dan sanitasi makanan. Menurut Nikmah (2018) terdapat empat faktor yang dapat dipenuhi untuk higine dan sanitasi makanan. Empat faktor yang disampaikan tersebut adalah tempat pengolahan, peralatan yang digunakan, orang yang mengolah dan bahan yang diolah. Selain itu, terdapat hal penting yang harus diperhatikan yaitu perlatan makan dan peralatan masak yang memiliki resiko kontaminasi bakteri patogen. 
Hal ini dipertegas dengan pendapat Aerita et al. (2014) bahwa keamanan olahan pangan yang dikonsumsi merupakan hal yang menyebabkan produk pangan aman untuk dikonsumsi dan bebas dari faktor yang dapat menimbulkan penyakit. Salah satu aspek yang harus dilakukan sehingga bahan pangan terbebas dari kontaminasi yang menimbulkan penyakit adalah higienitas dan sanitasi. Higienitas suatu bahan pangan dapat dilihat dari penjual bahan pangan tersebut, karena higienitas seseorang berpengaruh terhadap tingkat kontaminasi bakteri. Sedangkan sanitasi yang harus dijaga adalah lingkungan sekitar penjualan yaitu dapat dilihat sejak penanganan bahan baku hingga proses produksi bahan pangan.

\section{KESIMPULAN}

Kesimpulan dari hasil pengujian identifikasi bakteri patogen berdasarkan Inventory Lab Report yaitu 11 sampel olahan pangan di Terminal Tirtonadi Surakarta negatif terhadap cemaran V. cholera, Salmonella sp, dan B. cereus. Sedangkan, pada enam sampel dari sebelas sampel yang dilakukan pengujian dinyatakan positif terdapat cemaran bakteri E. coli.

\section{UCAPAN TERIMAKASIH}

\begin{tabular}{l}
\multicolumn{2}{c}{ Peneliti mengucapkan } \\
terimakasih kepada Laboratorium \\
Mikrobiologi Klinis Balai Besar \\
Teknik Kesehatan Lingkungan dan \\
Pengendalian Penyakit (BBTKLPP) \\
Yogyakarta yang telah memberikan \\
kesempatan untuk melaksanakan \\
penelitian tersebut.
\end{tabular}

\section{DAFTAR PUSTAKA}

Aminah, S., \& Hidayah, N. (2006). Pengetahuan keamanan pangan penjual makanan jajanan di lingkungan sekolah kelurahan wonodri kecamatan semarang selatan kota semarang. Jurnal Litbang, 4(3).

Aerita, A. N. (2014). Hubungan higiene pedagang dan sanitasi dengan kontaminasi Salmonella pada daging ayam potong. Unnes Journal of Public Health, 3(4).

Arlita, Y. (2014). Identifikasi Bakteri Escherichia Coli Dan Salmonella SP. Pada Makanan Jajanan Bakso Tusuk Di Kota Manado. eBiomedik, 2(1).

Ekawati, E. R., Yusmiati, S. N. H., \& Hamidi, F. R. (2017). Deteksi Escherichia coli Patogen pada pangan menggunakan metode konvensional dan metode multiplex PCR. Jurnal Sains Health, 1(2), 75-82.

Kartika, E., Khotimah, S., \& Yanti, A. H. (2014). Deteksi bakteri indikator keamanan pangan pada sosis daging ayam di pasar flamboyan Pontianak. Protobiont, 3(2). 
Kurniadi, Y., Saam, Z., \& Afandi, D. (2013). Faktor kontaminasi bakteri E. coli pada makanan jajanan dilingkungan kantin sekolah dasar wilayah Kecamatan Bangkinang. Jurnal Ilmu Lingkungan, 7(1), 28-37

Kurniasih, R. P., \& Nurjazuli, N. (2015). Hubungan higiene dan sanitasi makanan dengan kontaminasi bakteri Escherichia coli dalam makanan di warung makan sekitar terminal borobudur, Magelang. Jurnal Kesehatan Masyarakat (e-Journal), 3(1), 549-558.

Nikmah, M. (2018). Pemeriksaan mikrobiologi sampel makanan di RSUD Dr. Soetomo Surabaya. Jurnal Kesehatan Lingkungan, 10(3), 283-290.

Rahmani, N., \& Handayani, S. (2016). Kontaminasi bakteri Eschericia coli pada makanan dan minuman penjual jajanan di lingkungan pendidikan muhammadiyah limau, Jakarta Selatan. ARKESMAS (Arsip Kesehatan Masyarakat), 1(1).

Ruriani, E. (2010). Investigasi Bacillus cereus dan Salmonella pada nasi goreng pedagang kaki lima di sekitar kampus universitas jember. Jurnal Agroteknologi, 4(01), 68-75.

Sari, R., \& Apridamayanti, P. (2014). Cemaran bakteri Escherichia coli dalam beberapa makanan laut yang beredar di pasar tradisional Kota Pontianak. Kartika: Jurnal Ilmiah Farmasi, 2(2), 14-19.

Surjawidjaja, J. E., Salim, O. C., Bukitwetan, P., \& Lesmana, M. (2016). Perbandingan agar Mac Conkey, Salmonella-Shigella, dan Xylose Lysine Deoxycholate untuk isolasi Shigella dari usap dubur penderita diare. Universa Medicina, 26(2), 57-63.

Swanenburg, M., Urlings, H. A. P., Keuzenkamp, D. A., \& Snijders, J. M. A. (2001). Salmonella in the lairage of pig slaughterhouses. Journal of food protection, 64(1), 12-16

Turner, K.M., Restaino, L., \& Frampton, E. W. (2000). Efficacy of chromocult coliform agar for coliform and Escherichia coli detection in foods. Journal of food protection, 63(4), 539 - 541

Wahdiniati, L., Pantiwati, Y., \& Latia R. (2016). Pemeriksaan Kandungan Bakteri Salmonella sp. dan Bakteri Escherichia coli pada Petis Ikan di Pasar Klampis Bangkalan Madura (Dimanfaatkan sebagai Sumber Belajar Biologi) (Doctoral dissertation, University of Muhammadiyah Malang).

Widiyanto, T. (2018). Kajian parameter kimia dan mikrobiologi danau aneuk laot sebagai sumber air baku masyarakat Kota Sabang Provinsi Nanggroe Aceh Darussalam. LIMNOTEK-Perairan Darat Tropis di Indonesia, 24(2).

Yuniatun, T., Martini, M., Purwantisari, S., \& Yuliawati, S. (2017). Hubungan higiene sanitasi dengan kualitas mikrobiologis pada makanan gado-gado di 
A.N Falih, N.S Anindita \& E Kristanti / Jurnal Kesehatan 14(1) 2021, 36-47

Kecamatan Tembalang Kota Semarang. Jurnal Kesehatan Masyarakat (eJournal), 5(4), 491-499. 